\title{
Effectiveness of a multiple intervention strategy for the control of the tiger mosquito (Aedes albopictus) in Spain
}

\author{
Gisela Chebabi Abramides a , David Roiz ${ }^{\mathrm{b}}$, Raimon Guitart ${ }^{\mathrm{c}}$, Salvador Quintana ${ }^{\mathrm{d}}$, \\ Irene Guerrero $^{\mathrm{e}}$, Nuria Giménez ${ }^{\mathrm{c}, \mathrm{f}, *}$

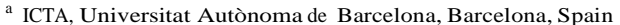 \\ b Wetland Ecology Department, Doñana Biological Station, Sevilla, Spain \\ ${ }^{c}$ Laboratory of Toxicology, Universitat Autònoma de Barcelona, Barcelona, Spain \\ d Hospital Mútua Terrassa, Research Foundation Mútua Terrassa, Universitat de Barcelona, Barcelona, Spain \\ e Departamento de Ecología, Universidad Autónoma de Madrid, Madrid, Spain \\ ${ }^{\mathrm{f}}$ Research Unit, Research Foundation Mútua Terrassa, Universitat de Barcelona, Barcelona, Spain
}

Keywords:

Aedes albopictus

Mosquito control

Ovitraps

Disease vectors

Pesticides

Source reduction a b s t r a c t

This study was undertaken to evaluate the effectiveness of four complementary and combined strategies to minimize the presence of the invasive mosquito Aedes albopictus, firmly established in Sant Cugat del Vallès, Catalonia, Spain. A quasi-experimental design including six neighbourhoods was performed in 2008-2009. The abundance of mosquitoes was monitored through ovitraps. The multiple intervention strategy consisted of four actions: source reduction; larvicide treatments (Bacillus thuringiensis israelensis and diflubenzuron); adulticide treatments (alfacipermetrin); and cleaning up uncontrolled landfills. The results showed the number of eggs significantly reduced in the areas with intervention. In 2008, the accumulate median of eggs was 175 and 272 in the intervention and control areas, respectively. In 2009, these medians were 884 and 1668 eggs. In total, 3104 households were visited and 683 people were interviewed. During inspections inside the houses, the cooperation of citizens in 2009 was 16\% higher than that in 2008 (95\% CI 13-19\%). These findings suggest that the strategy was effective in reducing the number of eggs. Citizen cooperation, an essential factor for success, was observed through a high level of collaboration by the home owners, who allowed entry into their private dwellings. This study could be a model for controlling the populations of Ae. albopictus in the Mediterranean region.

\section{Introduction}

The Asian tiger mosquito Aedes albopictus (Skuse 1894) (Diptera: Culicidae) is an invasive species, originally indigenous to the forests of Southeast Asia, that in recent decades

\footnotetext{
* Corresponding author. Present address: Research Unit, Research Foundation Mútua Terrassa, Universitat de Barcelona, C/ García Humet 24, E-08221 Terrassa, Barcelona, Spain. Tel.: +34 9358112 99; fax: +34935812959.

E-mail address: nuria.gimenez@uab.cat (N. Giménez).
}

has spread to many temperate and tropical regions of the world, including southern Europe. ${ }^{1-3}$ It was detected in Spain for the first time in Sant Cugat del Vallès, Catalonia, during the summer of 2004. ${ }^{4,5}$ Aedes albopictus is a synanthropic and daytime biting species. Its use of artificial containers in suburban landscapes as breeding sites was one of the reasons that contributed to its rapid geographic spread. $^{3}$ Nowadays the tiger mosquito has colonized 119 municipalities of Catalonia, affecting potentially approximately 5 million people. In Sant Cugat, Ae. albopictus is currently well established, becoming a major pest organism and affecting people's health and their quality of life. ${ }^{6}$ 
The tiger mosquito is dangerous, owing to its potential implications for public health. ${ }^{3,7,8}$ This species is capable of transmitting many diseases to humans, being an important vector of several arboviruses, such as dengue (DEN), chikungunya (CHIK) virus, yellow fever and several other types of encephalitis. ${ }^{1,8,9}$ DEN is the most important arboviral disease in the world, affecting more than 50 million people every year. Despite Ae. aegypti being responsible for most cases, Ae. albopictus has been associated with some outbreaks of DEN., ${ }^{1,8}$ An outbreak of CHIK fever in the summer of 2007 in northeast Italy, with 200 diagnosed cases, ${ }^{10}$ was the first confirmation that temperate Ae. albopictus populations could transmit a tropical virus imported by travellers and cause an epidemic in a colonized European area, creating an important health concern.

Although a number of control strategies for mosquitoborne diseases operate in different localities and countries, integrated vector management (IVM) techniques, such as source reduction (SR, a community-based approach), pesticide application, biological control, education and public awareness, as well as personal protection seem to offer the most promising results. ${ }^{7,11-13}$ An important point in carrying out long-term effective control is that it is necessary to include the collaboration of people who possess domestic points of breeding. ${ }^{11}$ Several researchers advocate that SR efforts are the only sustainable way to control Aedes (Stegomyia) vectors. ${ }^{14-17}$ Data show that once the tiger mosquito is established in a zone it is nearly impossible to eliminate it and very difficult to reduce the size of its population. ${ }^{18}$

The important spread of Ae. albopictus through all continents in recent decades, ${ }^{1,3}$ the importation of active cases of CHIK and DEN, ${ }^{8,19}$ the vectorial capacity for both viruse ${ }^{20}$ and the vulnerability of southern Europe to virus introduction ${ }^{2,21}$ emphasize the importance of development and application of strategies for IVM control methodologies. The aim of this study was to evaluate the efficiency of four complementary and combined strategies in the minimization of the Ae. albopictus population in one of the largest municipalities in Catalonia.

\section{Materials and methods}

\subsection{Study site}

The study was performed in Sant Cugat del Vallès $\left(41^{\circ} 28^{\mathrm{t}} 4^{\mathrm{tt}} \mathrm{N}, 1^{\circ} 53^{\mathrm{t}} 49^{\mathrm{tt}} \mathrm{E}, 48.32 \mathrm{~km}^{2}\right.$; mean elevation 172 $\mathrm{m})$ and the nearby municipality of Rubí $\left(41^{\circ} 29^{\mathrm{t}} 36^{\mathrm{tt}} \mathrm{N}\right.$, $02^{\circ} 01^{\mathrm{t}} 57^{\mathrm{tt}} \mathrm{E}, 32.30 \mathrm{~km}^{2}$; mean elevation $\left.123 \mathrm{~m}\right)$. Both are residential Catalan towns (population 82642 and 73691 inhabitants, respectively) with many parks and large areas of single houses with private gardens, courtyards and pools. The average annual rainfall is $605 \mathrm{~mm}$, and the average minimum temperature is $10.2{ }^{\circ} \mathrm{C}$, with a typical Mediterranean climate. Sant Cugat and Rubí are located at $15 \mathrm{~km}$ and $20 \mathrm{~km}$, respectively, northwest of Barcelona, from which both urban areas are biogeographically separated by the Natural Park of Collserola.

The six studied zones are depicted in Figure 1 and Table 1 . Areas 1 and 2 had intervention for two consecutive years: 2008 and 2009. Areas 3 and 4 were used as controls during 2008, but after the city council carried out SR programmes in all houses where citizens had complained or asked for technical support, they were included in 2009 as intervention areas. Control zones (areas 5 and 6) were located in Rubí, where the tiger mosquito was detected later and the city council had not promoted any Aedes spp. control programmes at the time of the study.

The study areas comprised mainly single-family dwellings and were segregated from surrounding neighbourhoods by large roads, woodlands or building complexes. There were 100 to 470 houses in each neighbourhood, and the mean lot size was $0.17-0.25$ ha. All housing and inhabitants in the six study areas were included, and only people who refused to participate in the study, those with mental disabilities and those $<16$ years were excluded.

\subsection{Study design}

This was a quasi-experimental study with multiple interventions, carried out from February to October in 2008 and from May to December in 2009, and consisted of four complementary strategies. The first of these was SR. House-to-house visits were carried out in each studied neighbourhood. The field workers asked for permission to enter the properties to educate the citizens about measures to prevent mosquito-borne disease. SR achieved through environmental sanitation of containers was used as a method for experimentally manipulating the production of immature Ae. albopictus in container habitats. As many residences as possible within neighbourhoods were surveyed for water-holding containers. In intervention areas, any water remaining in a container was discarded, and the container was turned over so that it would not collect rainwater. Any wet containers that could not be emptied were treated with an insect growth regulator larvicide (diflubenzuron $2 \%$ at a concentration of $1 \mathrm{~g} / \mathrm{hl}$ ) (Flower, Lleida, Spain). SR measures were conducted after adult householders gave verbal informed consent. The outcome of each visit was recorded in detail on a form and given to the city council.

The second measure was larvicide treatment with DEVICE TB2 (diflubenzuron $2 \%$ at $1 \mathrm{~g} / \mathrm{hl}$ ) in scuppers, water tanks and street drains containing stagnant water in the intervention areas. A granular formulation of the biolarvicide Bacillus thuringiensis israelensis (Bti), Vectobac G (EPA Registration No. 73049-10) (1.2\% Bti, 1 g/m²) (Valent BioSciences Corporation, Libertyville, IL, USA), was applied to seasonal streams. The third measure was sanitization of municipal sites and wooded terrains, with removal of uncontrolled rubbish dumps in the intervention zones. The fourth measure was adulticide treatment (Fastac 10\% alfacipermetrin $50 \mathrm{cc} / \mathrm{hl}$ ) (Basf Española S.A., Tarragona, Spain). Monthly, from July to October 2008-2009, insecticide was sprayed on the vegetation of some public gardens of each neighbourhood study area by specialized teams. These isolated fumigations were carried out, selecting two or three points in each intervention area, and giving priority to public gardens with the greatest number of users, as well as points located centrally in the intervention area to achieve a greater effect. $^{22}$ 
Table 1

Characteristics of study areas and the combined interventions performed during 2008 and 2009

\begin{tabular}{|c|c|c|c|c|c|c|c|c|c|c|c|c|c|}
\hline \multirow[t]{3}{*}{ Intervention } & & \multicolumn{5}{|l|}{2008} & \multicolumn{7}{|l|}{2009} \\
\hline & & \multicolumn{2}{|c|}{$\begin{array}{l}\text { Intervention } \\
\text { neighbourhoods }\end{array}$} & \multicolumn{2}{|c|}{$\begin{array}{l}\text { Control } \\
\text { neighbourhoods }\end{array}$} & \multirow{2}{*}{$\begin{array}{l}\text { Other areas } \\
\text { Standard }\end{array}$} & \multicolumn{2}{|c|}{$\begin{array}{l}\text { Intervention } \\
\text { neighbourhoods }\end{array}$} & \multicolumn{2}{|c|}{$\begin{array}{l}\text { Reintervention } \\
\text { neighbourhoods }\end{array}$} & \multicolumn{2}{|c|}{$\begin{array}{l}\text { Control } \\
\text { neighbourhoods }\end{array}$} & \multirow{2}{*}{$\begin{array}{l}\text { Other areas } \\
\text { Standard }\end{array}$} \\
\hline & & $\begin{array}{l}\text { Area } 1 \\
\text { Les Planes }\end{array}$ & $\begin{array}{l}\text { Area } 2 \\
\text { Can Cortès }\end{array}$ & $\begin{array}{l}\text { Area } 3 \\
\text { Mas Gener }\end{array}$ & $\begin{array}{l}\text { Area } 4 \\
\text { Can Barata }\end{array}$ & & $\begin{array}{l}\text { Area } 3 \\
\text { Mas Gener }\end{array}$ & $\begin{array}{l}\text { Area } 4 \\
\text { Can Barata }\end{array}$ & $\begin{array}{l}\text { Area } 1 \\
\text { Les Planes }\end{array}$ & $\begin{array}{l}\text { Area } 2 \\
\text { Can Cortès }\end{array}$ & $\begin{array}{l}\text { Area } 5 \\
\text { Can Ximelis }\end{array}$ & $\begin{array}{l}\text { Area } 6 \\
\text { Can Mir }\end{array}$ & \\
\hline & Area $\left(\times 10^{3} \mathrm{~m}^{2}\right)$ & 80.5 & 73.3 & 60.2 & 67.7 & 4700 & 60.2 & 67.7 & 80.5 & 73.3 & 60.0 & 60.2 & 4700 \\
\hline & $\begin{array}{l}\text { Number of } \\
\text { dwellings }\end{array}$ & 334 & 100 & 470 & 232 & 24014 & 470 & 232 & 334 & 100 & 150 & 280 & 24014 \\
\hline \multirow[t]{6}{*}{$\begin{array}{l}\text { Source } \\
\text { reduction }\end{array}$} & $\begin{array}{l}\text { Visited houses } \\
\mathrm{n}(\% \text { total } \\
\text { dwellings) }^{\mathrm{a}}\end{array}$ & 296 (89) & $48(48)$ & $61(13)$ & $18(8)$ & $1681(7)$ & 345 (89) & $109(46)$ & $80(24)$ & $46(46)$ & $17(11)$ & $20(7)$ & $383(2)$ \\
\hline & $\begin{array}{l}\text { Accessibility n } \\
(\%)^{\mathrm{b}}\end{array}$ & $145(49)$ & $33(69)$ & $39(64)$ & $13(72)$ & $926(55)$ & $174(50)$ & $61(56)$ & $25(31)$ & $13(28)$ & $14(82)$ & $14(70)$ & 281 (73) \\
\hline & $\begin{array}{l}\text { Inspections } \\
\text { inside the } \\
\text { house } \mathbf{n}(\%)^{\mathrm{b}}\end{array}$ & $42(14)$ & $6(12)$ & $15(25)$ & $3(17)$ & 209 (19) & 67 (19) & $24(22)$ & $12(15)$ & $12(26)$ & $1(1)$ & $3(1)$ & $172(49)$ \\
\hline & $\begin{array}{l}\text { Houses with } \\
\text { water holding } \\
\text { containers n } \\
(\%)^{\mathrm{b}}\end{array}$ & $152(51)$ & $21(43)$ & $32(52)$ & $10(55)$ & 709 (42) & $186(54)$ & $52(48)$ & $31(39)$ & $19(41)$ & $12(70)$ & $18(90)$ & $211(52)$ \\
\hline & $\begin{array}{l}\text { Houses with } \\
\text { larval habitats } \\
\text { n (\%) }\end{array}$ & $18(6)$ & 0 & $2(3)$ & $1(6)$ & $32(2)$ & $17(5)$ & $2(2)$ & $8(10)$ & $6(13)$ & 0 & 0 & $86(22)$ \\
\hline & $\begin{array}{l}\text { Interviews n } \\
(\%)^{\mathrm{b}}\end{array}$ & $91(31)$ & $11(23)$ & $17(28)$ & $5(5)$ & $303(18)$ & $70(20)$ & $27(27)$ & $20(25)$ & $12(26)$ & $4(23)$ & $6(30)$ & $107(28)$ \\
\hline Waste removal & Area (ha) $(\%)^{\mathrm{c}}$ & $0.5(0.8)$ & $0.1(0.1)$ & $0.5(0.8)$ & $0.2(0.0)$ & - & $1(1.7)$ & $0.4(0.6)$ & $0.3(0.4)$ & $0.3(0.4)$ & - & - & - \\
\hline $\begin{array}{l}\text { Adulticide } \\
\text { (periodic } \\
\text { treatment) }\end{array}$ & Area (ha) $(\%)^{\mathrm{c}}$ & $0.7(0.9)$ & $0.5(0.7)$ & - & - & - & $1(1.7)$ & $0.5(0.7)$ & $0.5(0.8)$ & $0.5(0.7)$ & - & - & - \\
\hline $\begin{array}{l}\text { Larvicide } \\
\text { (periodic } \\
\text { treatment) }\end{array}$ & $\begin{array}{l}\text { Number of } \\
\text { public sites } \\
\text { with larvicide } \\
\text { treatment (l) }\end{array}$ & $1(2)$ & $1(2)$ & - & - & - & $15(50)$ & - & $1(2)$ & $1(2)$ & - & - & - \\
\hline
\end{tabular}

${ }^{a}$ Total of dwellings in the area.

b Total of visits in the area.

${ }^{\mathrm{c}}$ Total of study area (ha). 


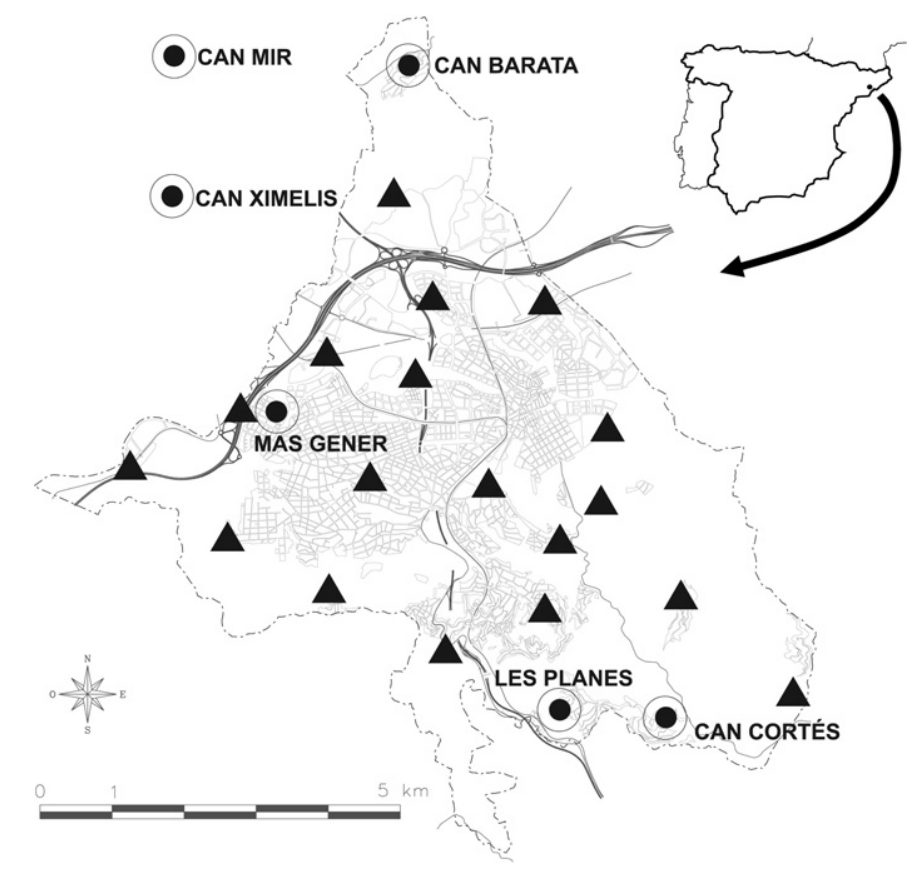

Figure 1. Geographic situation of the zones under study (see Table 1 for more details). The black triangles indicate the locations of oviposition traps in the standard area of the municipality of Sant Cugat del Vallès in 2008.

\subsection{Surveys}

A household was defined as one separate unit of accommodation (individual home or apartment) and the immediate surrounding premises, irrespective of the number of people residing within the unit. Information about housing type (principal domicile, empty house or service) from each household of the studied zones was collected. Neighbours from the whole municipality of Sant Cugat could also ask for technical support from the city council. All cases reported in this municipality were attended to with standard support: a civil agent inspected the household and SR measures were applied at the affected house and in all the houses that surrounded it; householders were interviewed and data were collected. The area and procedure were defined as standard. Good accessibility was defined as the situation in which the surfaces of the back yard or garden of the household were mostly visible even if the field workers could not enter it. When there was nobody at home at the time of the visit or when the citizens would not collaborate with the civil workers at the time of the inspection, an official letter emphasizing the need of collaboration with written and illustrated advice was sent, explaining how to avoid mosquito reproduction in the dwellings. Data were collected from some houses from control areas, selected randomly, and in those cases the inspections were carried out from outside the dwelling at the end of the season.

\subsection{Ovitraps}

About 15 oviposition traps (ovitraps) were allocated in each of the six study areas, approximately $200 \mathrm{~m}$ one from the other. Each sample station consisted of one ovitrap, a black plastic glass with a diameter of $14 \mathrm{~cm}$ filled with $300 \mathrm{ml}$ of clean water and containing a half-immersed piece of wood measuring $2.5 \times 12.5 \mathrm{~cm}$. The ovitraps were placed in sites shaded by vegetation in the treated and untreated neighbourhoods. The paddles were collected fortnightly and placed in individual plastic drawers that were sealed with parafilm and labelled. The water in the ovitrap was always checked for hatched mosquito larvae and/or pupae. Fresh tap water, new paddles and missing ovitraps were systematically replaced. Biolarvicide Bti was applied to prevent the production of mosquitoes in the trap. The number of eggs collected per trap was assessed by examination under a stereomicroscope $(40 \times)$. All the surfaces, including the edges, were checked and the eggs were counted. Population abundance was expressed by the mean and median number of eggs per positive trap. Because a small portion of the eggs laid (less than 5\%) could belong to other tree hole Aedes mosquitoes (Ae. geniculatus, Ae. echinus or Ae. berlandi) ${ }^{23}$, we raised them in the laboratory based on Roiz et al. (2008) to obtain larvae to confirm the identification of individuals. All the emerged larvae were identified as Ae. albopictus. This result, together with the results of other studies in the same area, ${ }^{24}$ confirmed that the eggs of the ovitraps were Ae. albopictus. The number of eggs represents the abundance of sexually active females. ${ }^{24}$ Ovitrap monitoring was performed from August to October in 2008 and from May to December in 2009. The months with greatest activity of Ae. albopictus were always studied, but with variation in the follow-up procedures, due to changes in the resources available each year. In 2008, as well as in the study zones, 18 ovitraps were homogeneously distributed through the town, corresponding to the standard municipality area. In 2009, the standard area was not monitored by ovitraps. 


\subsection{Statistical analysis}

Data were analysed with a negative binomial distribution generalized linear model (GLM). Missing data were replaced using the method of the median of adjacent points. The response variable was the egg abundance, the intervention type is an explanatory variable (factor) and month and area were introduced as covariates to control for their possible effect and to centre the analysis on the effect of the different level of the treatments ('control', 'intervention' and 'reintervention'). Analysis was performed using SPSS 17.0 (SPSS Inc., Chicago, IL, USA).

\section{Results}

In total, 2104 houses were visited in 2008, and 1000 in 2009. The main findings in the study areas of the four complementary interventions are shown in Table 1 . The number of citizens interviewed by questionnaire was 427 in 2008 and 246 in 2009. The distribution of the questionnaires was $60 \%$ in standard areas $(n=409), 34 \%$ in intervention areas $(n=230)$ and $6 \%$ in control areas $(n=44)$. In the intervention areas, $47 \%$ of the citizens interviewed (102 questionnaires) allowed the civil workers to enter their dwellings in 2008 and 90\% (128 questionnaires) did so in 2009.

At $9 \%$ of the visited houses it was not possible to see the back yards and gardens of the dwellings, specifically in $10 \%$ $(n=210)$ in 2008 and 6\% $(n=60)$ in 2009. Accessibility for years did not show differences in control and intervention areas, but in 2009 the accessibility to standard areas was 18\% higher than in 2008 (95\% CI 13-23\%). During inspections inside the houses, the cooperation of citizens in 2009 was 16\% higher than that of 2008 (95\% CI 13-19\%). About interviews, no differences were observed for years in the control areas, but an increase of 4\% was observed in 2009 in intervention and standard areas compared with 2008 (95\% CI 1-8\%). Also the detection of containers with stagnant water (95\% CI 1-13\%) and containers with production of immature mosquitoes (95\% CI 7-11\%) increased by $9 \%$ in 2009 compared with 2008.

Regarding the two other interventions in the study areas, larvicide treatment and clearance and waste removal, these were similar during 2008 and 2009, but adulticide treatment was applied four times in 2009 and only once in 2008. Selection of the insecticides used was based on data from recent literature. ${ }^{11,12,23}$ In relation to the standard areas, the number of cases reported to the city council was 206 in 2008 and 170 in 2009.

Results showed a significant reduction in numbers of mosquito eggs in treated areas compared with untreated areas in 2008 and 2009 (Figure 2). The median number of eggs was higher in 2009.

Table 2 shows the resulting model after statistical analysis. All three studied variables (intervention, area and month) affected the egg abundance $(\mathrm{P}<0.05)$. Control areas show significantly higher egg abundance than the other areas. Intervention areas also presented significantly higher egg abundance than the reintervention areas.

\section{Discussion}

The present study brings the first evidence in Europe of the effectiveness of IVM for control of the tiger mosquito. At present, there have been only a few examples of successful Aedes spp. control, ${ }^{3,15}$ and until now the only achievement has been a transitory density control. ${ }^{16,25}$ Around the world, the majority of programmes for Aedes spp. control have been focused mainly on Ae. aegypti, and initial studies have been directed towards the more ambitious goal of eradication. $^{26-28}$ However, the results obtained have been considered a 'global disaster'. ${ }^{29}$ Both species have their own peculiarities, with consequences for the most suitable control strategies. ${ }^{1,2,7,11,13}$

Currently, the most practical method accepted and used to detect and estimate the population of Aedes spp. adult mosquitoes in the environment is the ovitrap. ${ }^{13,30}$ The advantages of ovitraps are that they are inexpensive and sensitive, and it is possible to install them in large areas relatively quickly. One problem is that there are some theoretical controversies about the use of ovitrap data for assessing adult populations in high densities. ${ }^{30}$ However, in 2009 Wan Norafikah et al. applied the ovitrap index as an indicator of a degree of infestation in specified areas. ${ }^{13}$

The combination of the four IVM strategies was effective in reducing the number of eggs. Furthermore, we observed a decrease in the number of eggs over time: in 2009 fewer eggs were detected in the reintervention areas compared with the intervention ones, and these differences were statistically significant, which suggests that the door-to-door communication programme can have a long-term effect on the behaviour of the population.

Collaboration of the local population is so important that 'closed' houses signify a failure of the intervention. ${ }^{26}$ Being a key factor for success, the cooperation of the community was requested repeatedly during the house-tohouse intervention. The majority of the people gave access to their property, allowing civil agents to eliminate breeding points in the gardens and back yards, and once they had been informed of the prevention measures they cooperated in the detection of potential breeding points in the areas surrounding their property.

The fact that different areas had an influence in mosquito abundance highlights the spatial heterogeneities between neighbourhoods with the same treatments but different effects owing to socioeconomic differences (e.g. characteristics of peoples' responses to the communication campaigns) and ecological differences (e.g. mosquito breeding sites, vegetation, population density). The effect of month on mosquito abundance is due to the intrinsic effect of the seasonal dynamics of the tiger mosquito, which vary over time depending on the dynamics of the meteorological variables. ${ }^{31}$

A greater number of containers were detected with growth of mosquito larvae and pupae in 2009 and a higher percentage of containers with standing water compared with 2008. This may be owing to the increased accessibility and inspections inside the private gardens or homes in the second year of study, and the greater involvement and cooperation of citizens. 

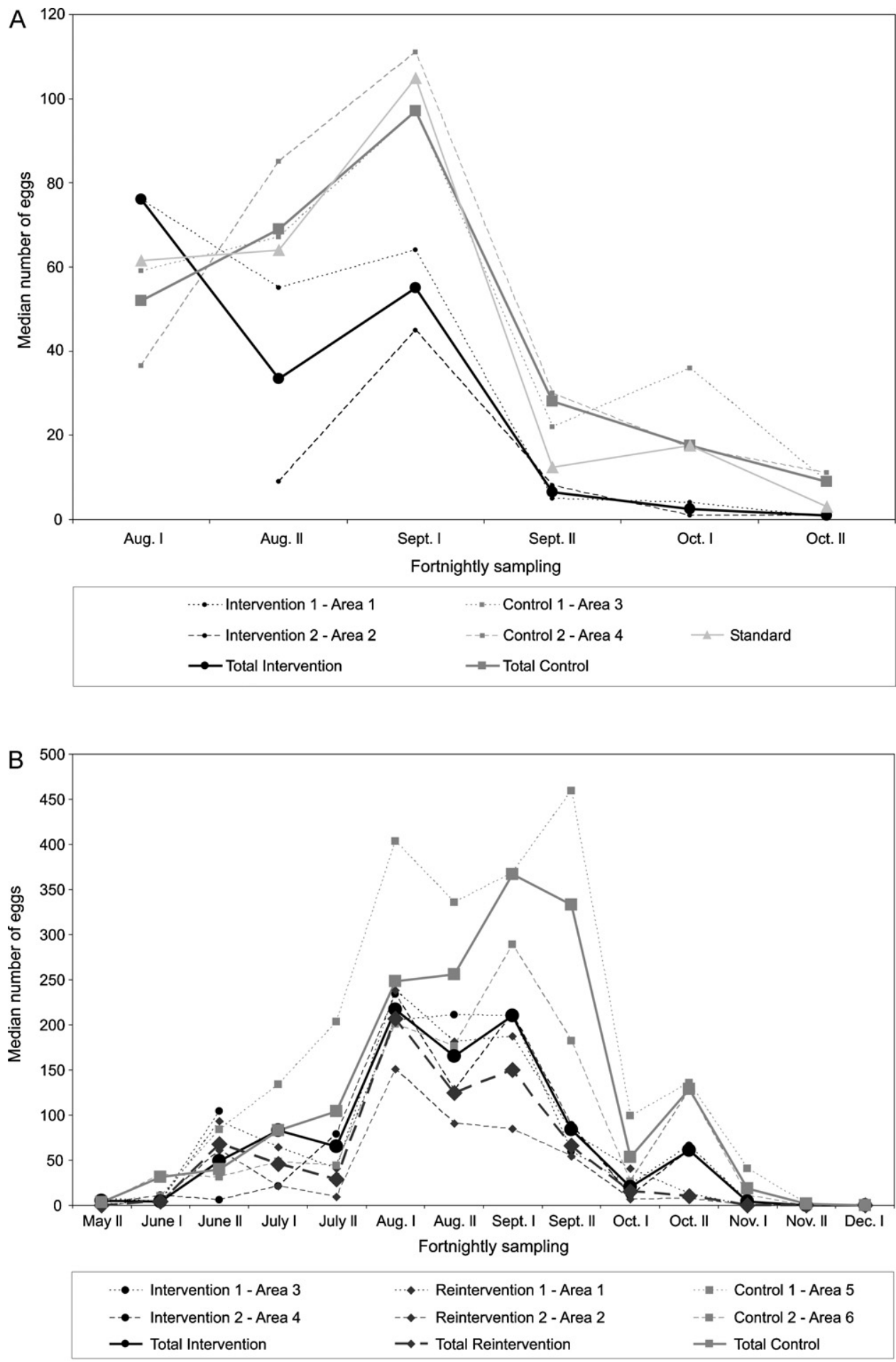

Figure 2. Evolution of the medians of eggs of Aedes albopictus with fortnightly sampling from August to October 2008 (A) and May to December 2009 (B)

The number of eggs increased notably in 2009 compared with 2008, showing that the mosquito population is still increasing after at least 5 years of colonization. ${ }^{23}$ Initially, the arrival of Ae. albopictus was seen as very bothersome by the local people, ${ }^{6}$ and demand for medical attention for this reason peaked in $2004,{ }^{5}$ diminishing thereafter. Also the cases handled by the local council diminished progressively from 2006. We consider that the reduced demand both for medical aid and help from the council was due to better knowledge of prevention and control methods and 
Table 2

Results of the fortnightly sampling in 2009 using the negative binomial distribution generalized model analysis

\begin{tabular}{|c|c|c|c|c|c|c|c|}
\hline Response variable & & & p (95\% CI) & Std. error & Wald $y^{2}$ & df & P-value \\
\hline \multirow[t]{5}{*}{ Egg abundance } & Intercept & & $2.099(1.643-2.555)$ & 0.2324 & 81.540 & 1 & $<0.001$ \\
\hline & Factor & Control & $0.721(0.572-0.869)$ & 0.0757 & 90.569 & 1 & $<0.001$ \\
\hline & & $\begin{array}{l}\text { Intervention } \\
\text { Reintervention }^{\mathrm{a}}\end{array}$ & $0.155(0.004-0.307)$ & 0.0773 & 4.025 & 1 & 0.045 \\
\hline & Covariates & Area & $0.047(0.011-0.084)$ & 0.0186 & 6.445 & 1 & 0.011 \\
\hline & & Month & $0.287(0.233-0.341)$ & 0.0275 & 109.216 & 1 & $<0.001$ \\
\hline
\end{tabular}

${ }^{\mathrm{a}}$ Reference category.

a possible progressive diminishing in intensity of the local immune response.

In Spain the interventions follow different local protocols, which could be improved by the application of a unified common strategy for the whole Mediterranean area. The combined four measures tested here seem to have provided benefits locally, although chemical or biological insecticidal products used may vary based on availability, regulations or evolution of resistances. ${ }^{7,24}$ Better results of this IVM are expected, particularly if the techniques are geographically expanded and maintained for a sufficiently long period of years, and if the collaboration of the citizens is requested (enforcement laws should be considered) and education programmes permanently granted.

\section{Conclusion}

The combination of the four IVM strategies was clearly effective in reducing the number of eggs in the intervention areas compared with the control ones. A high level of public cooperation was obtained from the beginning, and furthermore this continued to increase as the interventions were carried out. The citizens allowed internal inspection of their properties and provided information about possible breeding points in the neighbourhood. This study could be a model for controlling the populations of Ae. albopictus in the Mediterranean region.

Authors' contributions: GCA conceived and designed the study, conducted the experimental field work, secured funding, extracted, analysed and interpreted the results and wrote the manuscript; DR conceived and designed the study, secured funding, analysed and interpreted the results and wrote the manuscript; RG participated in the interpretation of data and wrote the final draft; SQ and IG analysed and interpreted the results and revised the manuscript critically for intellectual content; NG conceived and designed the study, secured funding, analysed and interpreted the results and wrote the manuscript. All authors reviewed the final manuscript. GCA and NG are guarantors of the paper.

Acknowledgements: The authors wish to express their gratitude to A. Domingo, M. Martori and F. Alés for their help in the graphics and the map layouts. We thank $\mathbf{M}$. Gilliland for correcting the English and V. Magdaleno for his great field work. We are indebted to S. Cantó, N. Curcó, R. Hernández and S. van den Hove for their generous collaboration, for helpful comments and for securing funding. We are also very grateful to the people of Sant Cugat and Rubí, for allowing us to work in their homes and their support, cooperation and assistance with this study.

Funding: This work was supported by grants 2008ACOM0082 and 2009ACOM0093 of the Agència de Gestió d'Ajuts Universitaris i de Recerca (AGAUR) and by Comissionat per Universitats i Recerca.

Conflicts of interest: None declared.

Ethical approval: The verbal informed consent of the citizens was obtained. The present study was done in accordance with the Research Ethics Committee of Mútua Terrassa Hospital, Barcelona, Spain.

\section{References}

1. Gratz NG. Critical review of the vector status of Aedes albopictus. Med Vet Entomol 2004;18:215-27.

2. Delaunay P, Jeannin C, Schaffner F, Marty P. Actualités 2008 sur la présence du moustique tigre Aedes albopictus en France métropolitaine. Arch Pediatr 2009;16(Suppl 2):66-71.

3. Paupy C, Delatte H, Bagny L, Corbel V, Fontenille D. Aedes albopictus, an arbovirus vector: from the darkness to the light. Microbes Infect 2009;11:1177-85.

4. Aranda C, Eritja R, Roiz D. First record and establishment of the mosquito Aedes albopictus in Spain. Med Vet Entomol 2006;20:150-2.

5. Giménez N, Barahona M, Casasa A, Doming A, Gavagnach M, Martí C. Llegada de Aedes albopictus a España, un nuevo reto para la salud pública. Gac Sanit 2007;21:25-8.

6. Curco N, Gimenez N, Serra M, Ripoll A, Garcia M, Vives P. Asian tiger mosquito bites: perception of the affected population after Aedes albopictus became established in Spain. Actas Dermosifiliogr 2008;99:708-13.

7. Esu E, Lenhart A, Smith L, Horstick O. Effectiveness of peridomestic space spraying with insecticide on dengue transmission; systematic review. Trop Med Int Health 2010;15:619-31.

8. Weaver SC, Reisen WK. Present and future arboviral threats. Antiviral Res 2010;85:328-45.

9. Mitchell CJ. Geographic spread of Aedes albopictus and potential for involvement in arbovirus cycles in the Mediterranean Basin. J Vector Ecol 1995;20:44-58.

10. Angelini R, Finarelli AC, Angelini P, Po C, Petropulacos K, Macini P, et al. An outbreak of chikungunya fever in the province of Ravenna, Italy. Euro Surveill 2007; 7:319-27.

11. Heintze C, Velasco Garrido M, Kroeger A. What do community-based dengue control programmes achieve? A systematic review of published evaluations. Trans R Soc Trop Med Hyg 2007;101:317-25.

12. Ballenger-Browning KK, Elder JP. Multi-modal Aedes aegypt mosquito reduction interventions and dengue fever prevention. Trop Med Int Health 2009;14:1542-51.

13. Wan Norafikah O, Chen CD, Soh HN, Lee HL, Nazni WA, Sofian Azirun M. Surveillance of Aedes mosquitoes in a university campus in Kuala Lumpur, Malasya. Trop Biomed 2009;26:206-15.

14. Winch P, Leontsin E, Rigau-Pérez G, Ruiz-Perez M, Clark GG, Gubler DJ. Community-based dengue prevention programs in Puerto Rico: impact on knowledge, behavior, and residential mosquito infestation. Am J Trop Med Hyg 2002;67:363-70.

15. Kittayapong P, Yoksan S, Chansang U, Chansang C, Bhurmiratana A. Suppression of dengue transmission by application of integrated 
vector control strategies at sero-positive GIS-based foci. Am J Trop Med Hyg 2008;78:70-6.

16. Richards SL, Ghosh SK, Zeichner C, Apperson CS. Impact of source reduction on the spatial distribution of larvae and pupae of Aedes albopictus (Diptera: Culicidae) in suburban neighborhoods of a Piedmont community in North Carolina. J Med Entomol 2008;45:617-28.

17. Horstick O, Runge-Ranzinger S, Nathan MB, Kroeger A. Dengue vector-control services: how do they work? A systematic literature review and country case studies. Trans R Soc Trop Med Hyg 2010;104:379-86.

18. Enserink M. Entomology. A mosquito goes global. Science 2008;320:864-6.

19. Sánchez-Seco MP, Negredo AI, Puente S, Pinazo MJ, Shuffenecker I, Tenorio A, et al. Diagnóstico del virus chikungunya importado en España (2006-2007): Detección de casos en viajeros. Enferm Infecc Microbiol Clin 2009;27:457-61.

20. Talbalaghi A, Moutailler S, Vazeille M, Failloux AB. Are Aedes albopictus or other mosquito species from northern Italy competent to sustain new arboviral outbreaks? Med Vet Entomol 2010;24: 83-7.

21. Fontenille D, Failloux A, Romi R. Should we expect chikungunya and dengue in Southern Europe? In: Takken W, Knols B, editors. Emerging pests and vector-borne diseases in Europe. Wageningen, The Netherlands: Wageningen Academic Publishers; 2007. p. 169-84.

22. Baseggio A. Availability of insecticidal molecules to control Aedes albopictus (Skuse). Parassitologia 2008;50:99-101.
23. Zamburlini R, Frilli F. La correta identificazione delle uova di Aedes albopictus. Disinfestazione 2003; Marzo-Aprile:8-10.

24. Roiz D, Eritja R, Molina R, Melero-Alcibar R, Lucientes J. Initial distribution assessment of Aedes albopictus (Diptera: Culicidae) in the Barcelona, Spain, Area. J Med Entomol 2008;45:347-52.

25. Kay BH, Nam VS, Tien TV, Yen NT, Phong TV, Diep TVB, et al. Control of Aedes vectors of dengue in three provinces of Vietnam by use of Mesocyclops (Copepoda) and community-based methods validated by entomologic, clinical, and serologic surveillance. Am J Trop Med Hyg 2002;66:40-8.

26. Chadee DD. Effects of 'closed' houses on the Aedes aegypti eradication programme in Trinidad. Med Vet Entomol 1988;2:193-8.

27. Gubler DJ. Aedes aegypti and Aedes aegypti-borne disease control in the 1990s: top down or bottom up. Am J Trop Med Hyg 1989;40:571-8.

28. Nam VS, Nguyen TY, Kay BH, Marten GG, Reid JW. Eradication of Aedes aegypti from a village in Vietnam, copepods and community participation. Am J Trop Med Hyg 1998;59:657-60.

29. Kay B, Nam VS. New strategy against Aedes aegypti in Vietnam. Lancet 2005;365:613-7.

30. Focks DA. A review of entomological sampling methods and indicators for dengue vectors. Geneva: WHO Special Programme for Research and Training in Tropical Diseases (TDR); 2003. TDR/IDE/Den/03.1.

31. Roiz D, Rosà R, Arnoldi D, Rizzoli A. Effects of temperature and rainfall on the activity and dynamics of host-seeking Aedes albopictus females in northern Italy. Vector Borne Zoonotic Dis 2010;10:811-6. 